\title{
A Tribute to Jean-Claude Healy, a Free Thinker and Visionary Leader for Biomedical Informatics
}

On 21st of March, 2008, the Medical Informatics community lost a free thinker, a true optimist and a humanitarian who tirelessly worked towards a new era of eHealth in Europe and beyond. Jean-Claude Healy passed away very prematurely and suddenly, in his house in Arenas, Saint Jean du Gard at the age of 65 .

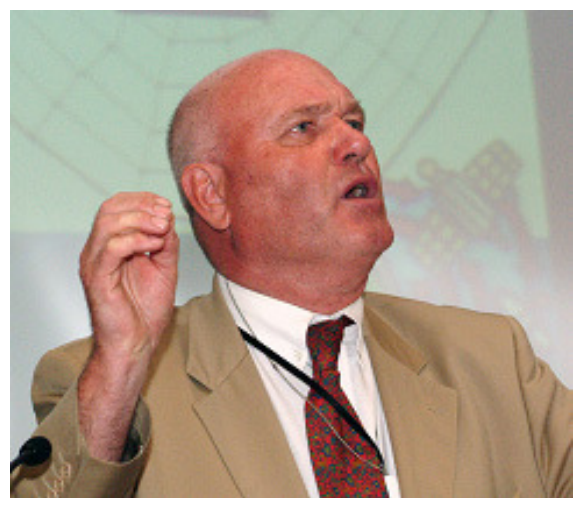

Under Jean-Claude's supervision, the medical informatics research community strengthened its world-wide impact and established the European Union as a world leading institution supporting medical informatics. Under his leadership the funding of the EU medical informatics (health telematics, eHealth) programs has increased fivefold. JeanClaude himself was the driving force behind the concepts and initiatives that focused on providing tools and intelligent environments directly to patients, supporting them in health promotion and lifestyle management. He was the originator and strong supporter of the Healthgrid concept, dreaming of connected health research communities freely sharing information and knowledge. In 2001 we have taken a bold decision to bring diverse scientific fields of medical informatics, bioinformatics and neuroinformatics together under the umbrella of Biomedical Informatics field. Our ambitious goal of providing the integrated view of human physiology and diseases from the level of molecule to the levels of organ, system and population is now becoming a mainstream research target, supported by the EU and other international research programs.

Jean-Claude's main strength was to bring the right people together when there was a call for action. He convinced his staff in 2003 that the time was ripe to call for an EU-wide eHealth Action Plan. We have gathered the Health Ministers, under the first eHealth Ministerial conference, to lay the evidence in front of them and commit them to action. These actions are already bearing fruit. Deployment of beneficial eHealth solutions on local, regional and national scales has accelerated tremendously, directly or indirectly influenced by the EU's call for action. Jean-Claude took even bolder steps in committing authorities to eHealth by working relentlessly for 2 years in the WHO until the eHealth Resolution (WHA 58 28) and the WHO eHealth action plan was adopted for all 193 WHO Member States.

The achievements of Jean-Claude were based on his previous 30 years of experience as Professor in the areas of biophysics and medical informatics. Jean-Claude Healy, PhD MD (University of Paris) was a Professor of Biophysics and Medical Informatics at the Universities of Paris, Strasbourg, and St. Etienne from 1965 to 1995 . In 1995 he joined the European Commission as Head of the Health Telematics unit, a position which he held until 2004. From 2004 to 2006 he was advisor to WHO where he held the position of a Director in the Office of External Relations and Governing Bodies in charge of the WHO eHealth strategy. Before his retirement from the European Commission in November of 2007, Jean-Claude held also a Senior Advisor position for several months in the United Nations office for Global Alliance for ICT and Development (GAID) striving to promote worldwide deployment of tools and skills needed to reap the benefits of technology. The diversity and richness of his 250 publications span from basic research in biophysics to experimental work in medical informatics to policy documents such as the WHO eHealth Resolution and eHealth Action Plan and the EU-WHO eHealth report for the World Summit on Information Society.

Jean-Claude was a friend, with a generous and enthusiastic nature, with a permanent sense of humour. I had the privilege and fun to work with JeanClaude for over 10 years as colleague and later as his deputy of the eHealth unit of the European Commission. I will cherish the memory and be always thankful for the trust and freedom he provided me all these years. I am committed to pursue his visions and activities which we started together and in this way keep him alive in our community. I will finish with his favorite quote:

"The reasonable man adapts himself to the world; the unreasonable one persists in trying to adapt the world to himself. Therefore, all progress depends on the unreasonable man."

George Bernard Shaw

Ilias Iakovidis, $\mathrm{PhD}$

Deputy Head-ICT for Health DG Information Society and Media European Commission 